\title{
Validations of pheromone trap designs for the management of brinjal shoot and fruit borer, Leucinodes orbonalis (Crambidae: Lepidoptera)
}

\section{P Dominic Manoj, G Ravi, S Sithanantham, K Elanchezhyan \& MI Manivannan}

Journal of Agriculture and Ecology

ISSN: $2456-9410$

Volume: 8

Journal of Agriculture and Ecology (2019) 8: 70-74 http://doi.org/10.53911/JAE.2019.8209

\section{Volume-8 (December, 2019) ISSN: $2456-9410$ Journal of Agriculture and Ecology}
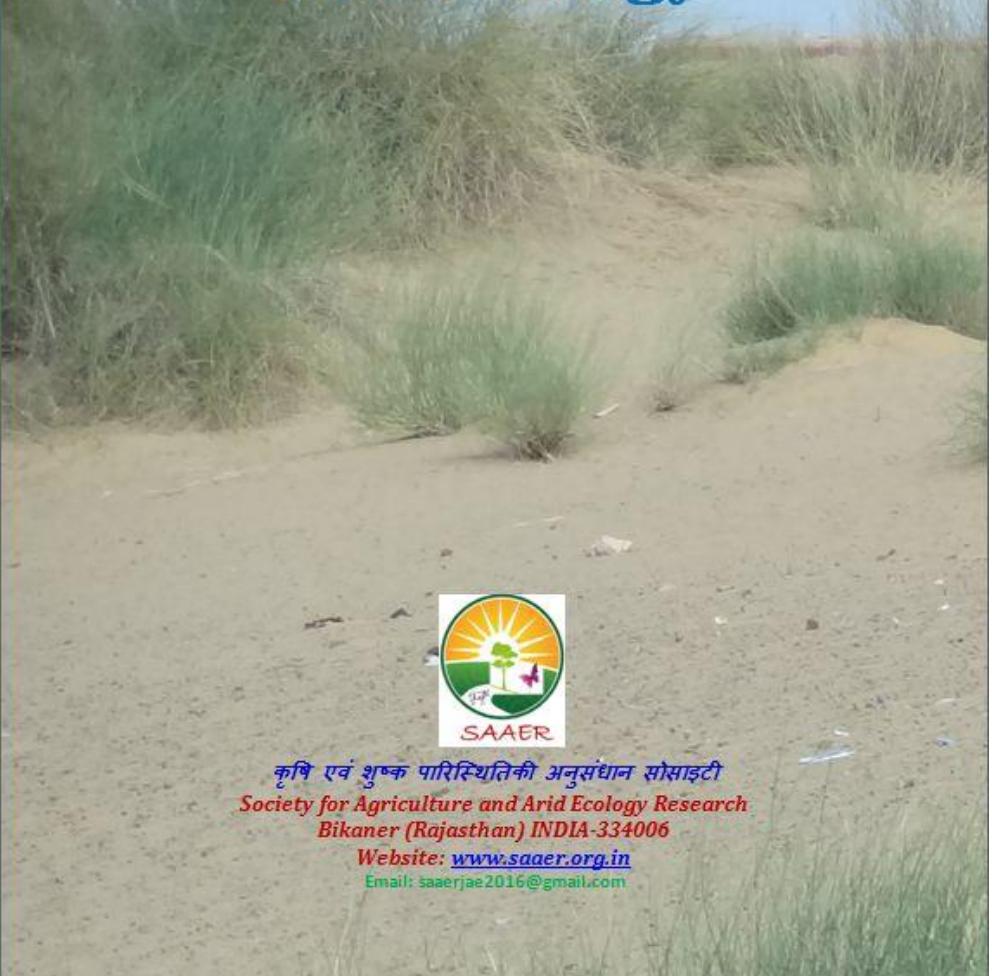
Validations of pheromone trap designs for the management of brinjal shoot and fruit borer, Leucinodes orbonalis (Crambidae: Lepidoptera)

P Dominic Manoj $^{1}$, G Ravi $^{2}$ Z, S Sithanantham ${ }^{3}$, K Elanchezhyan ${ }^{1}$ \& MI Manivannan ${ }^{4}$

${ }^{1}$ Department of Agricultural Entomology, Agricultural College and Research Institute, Tamil Nadu Agricultural University, Killikulam, Vallanadu, Thoothukudi, Tamil Nadu, India.

${ }^{2}$ Department of Plant Protection, Anbil Dharmalingam Agricultural College and Research Institute,

Tamil Nadu Agricultural University, Tiruchirappalli, Tamil Nadu, India.

${ }^{3}$ Sun Agro Biotech Research Centre, 3/1978, Main road, Madanandapuram Mugalivakkam, Porur, Chennai, Tamil Nadu, India.

${ }^{4}$ Department of Horticulture, Agricultural College and Research Institute, Tamil Nadu Agricultural University, Killikulam, Vallanadu, Thoothukudi, Tamil Nadu, India.

DI Corresponding author: G Ravi, Email: entoravi@yahoo.com

\section{Article Info}

Article history

Received: 20 September 2018

Accepted: 15 November 2018

Available online: 5 August 2019

Key Words: Leucinodes orbonalis, traps design, traps erection height.

\section{Abstract}

The brinjal shoot and fruit borer, Leucinodes orbonalis is the most noxious and destructive pest of brinjal and widely distributed in South Asian countries. The yield loss up to $80 \%$ was recorded in brinjal cultivation by the infestation of $L$. orbonalis. Two different studies were conducted in farmer's field at Tuticorin, Tamil Nadu, India during Rabi 2017 to evaluate the efficacy of 1) Trap designs 2) Trap errection height. The comparison made on moth retention pattern of commercial Traps and indigenous bottle trap, indicated a significantly different between trap designs. Maximum mean number of moth catches was recorded in Indigenous bottle trap (1.937 moths/ day/ trap). Among the trap heights tested, trap placed at crop canopy level attracted maximum moths (3.54 moths/3 trap/day). Trap moth catch was superior in indigenous trap placed at crop canopy level.

Copyright (02019 Dominic Manoj et al., This is an open access article published under the terms of the Creative Commons Attribution License, which permits unrestricted use, distribution, and reproduction in any medium, provided the original work is properly cited.

Preferred citation: Dominic Manoj P, Ravi G, Sithanantham S, Elanchezhyan K \& Manivannan MI. 2019. Validations of pheromone trap designs for the management of brinjal shoot and fruit borer, Leucinodes orbonalis (Crambidae: Lepidoptera). Journal of Agriculture and Ecology, 8: 70-74; http://doi.org/10.53911/JAE.2019.8209.

\section{Introduction}

Brinjal, Solanum melongena (L.) is the economically important vegetable crop cultivated throughout the India (Javed et al., 2017). It is a bushy plant and also called eggplant belongs to Solanaceae family. It is grown extensively in more than 729 thousand hectares in India with an annual production of 12.62 MT (Anon 2018). Among the pests the brinjal shoot and fruit borer (BFSB), Leucinodes orbonalis Guenee (Crambidae: Lepidoptera) is the most serious and destructive pests of brinjal crop. The wide range of insecticides including synthetic pyrethroids is regularly being used for the control of L. orbonalis. the regular and indiscriminate use of these pesticides lead to resurgence of sucking pests like whitefly, aphid and mite (Srinivasan 2009) and also 
hazardous to the ecosystems. So there is urgent need for Integrated Pest Management (IPM) mediated pest management system for controlling of BFSB in brinjal crop. Among the different IPM approaches available, the use of sex pheromone become one of the prospective alternate to sole use of chemical pesticides in brinjal crop. Therefore, the present study was to concentrate on assessing the performance of commercially available trap designs which help to select proper pheromone trap design with suitable erection height. This findings leads to reduce the indiscriminate use of insecticides in brinjal cultivation against brinjal shoot and fruit borer, L. orbonalis.

\section{Materials and Methods}

Evaluate the role of pheromone traps as pull component in suppressing $L$. orbonalis build up

Field investigations were carried out in the brinjal field for assessing the performance of commercially available trap designs for shoot and fruit borer. The experiment was conducted at irrigated condition during Rabi 2017 at Deivaseiyalapuram village of Tuticorin district of Tamil Nadu. The brinjal seedlings of KKM1 cultivar were transplanted in a one acre of land and crop was raised as per the recommended package of practices. Soon after transplanting the seedling into field, different models of traps Viz., commercial models of water trap, sleeve trap, TNAU master trap and locally prepared indigenous bottle trap were installed in the field at $10 \mathrm{~m} \times 10 \mathrm{~m}$ distance. The experiment was laid out in randomized block design with following five treatments and six replications. Different trap designs compared were as follows: T1 water trap (PCI Commercial Model); T2 sleeve trap (PCI Commercial Model); T3 TNAU master trap; T4 indigenous bottle trap; T5 untreated control
Moth recruitment pattern of indigenous bottle trap placed in different position

The moth recruitment pattern of indigenous bottle trap placed in different position was studied in farmer's field trial conducted at Meenachipatti village of Tuticorin district of Tamil Nadu. In one acre of land the brinjal seedlings of KKM1 cultivar were transplanted and crop was raised as per the recommended package of practice. The experiment was conducted in Rabi 2017. The trap was installed in three different position viz. in ground level (T1), in crop canopy level (T2) and above the canopy level (T3) for assessing the appropriate level of the trap for recruiting maximum moths. In ground level, the trap bottom board was placed over the earth surface and then to the crop canopy and above the crop canopy level the trap was installed with the help of trap stand. The experiment was laid out in RBD with three treatments and it was replicated in seven times.

\section{Result and Discussion}

Compare the moth recruitment pattern of different trap designs for integration in $L$. orbonalis management

The results of the observation taken from brinjal crop in Deivaseiyalapuram village from January $2^{\text {nd }}$ week to April $4^{\text {rd }}$ week are furnished in Table 1 . The number of moth catches was significantly different between the different trap designs studied (Fig. 1). A maximum mean number of moth catches was recorded in indigenous bottle trap (1.937 moths/ day/ trap) followed by TNAU master trap (1.874 moths/day/trap) and a minimum moth catches was observed in commercial water trap 1.354 moths per day and in the Sleeve trap the catche was 1.278 moth. Alam et al. (2003), Haldhar et al. 2014 and Mathi \& Ravi (2018) reported the importance of trap design in sex pheromone use for the control of L. orbonalis in brinjal. 


\begin{tabular}{ccc}
\hline Treatment & Trap designs & Overall mean/trap \\
\hline \multirow{2}{*}{$\mathrm{T}_{1}$} & Wota-T trap & $1.354^{\mathrm{b}}$ \\
& & $(1.163)$ \\
$\mathrm{T}_{2}$ & Sleeve trap & $1.278^{\mathrm{bc}}$ \\
& & $(1.130)$ \\
$\mathrm{T}_{3}$ & TNAU Master trap & $1.874^{\mathrm{a}}$ \\
& & $(1.368)$ \\
$\mathrm{T}_{4}$ & Indigenous Bottle trap & $1.937^{\mathrm{a}}$ \\
& SEm & $(1.391)$ \\
& SEd & 0.04 \\
& CD $(0.05)$ & 0.06 \\
& CD $(0.01)$ & 0.137 \\
\hline
\end{tabular}

Table 1. Compare the Moth retention pattern of different Trap designs

Figures in the parentheses are based on square root transformation, DMRT

Fig. 1 Moth retention pattern of different trap designs

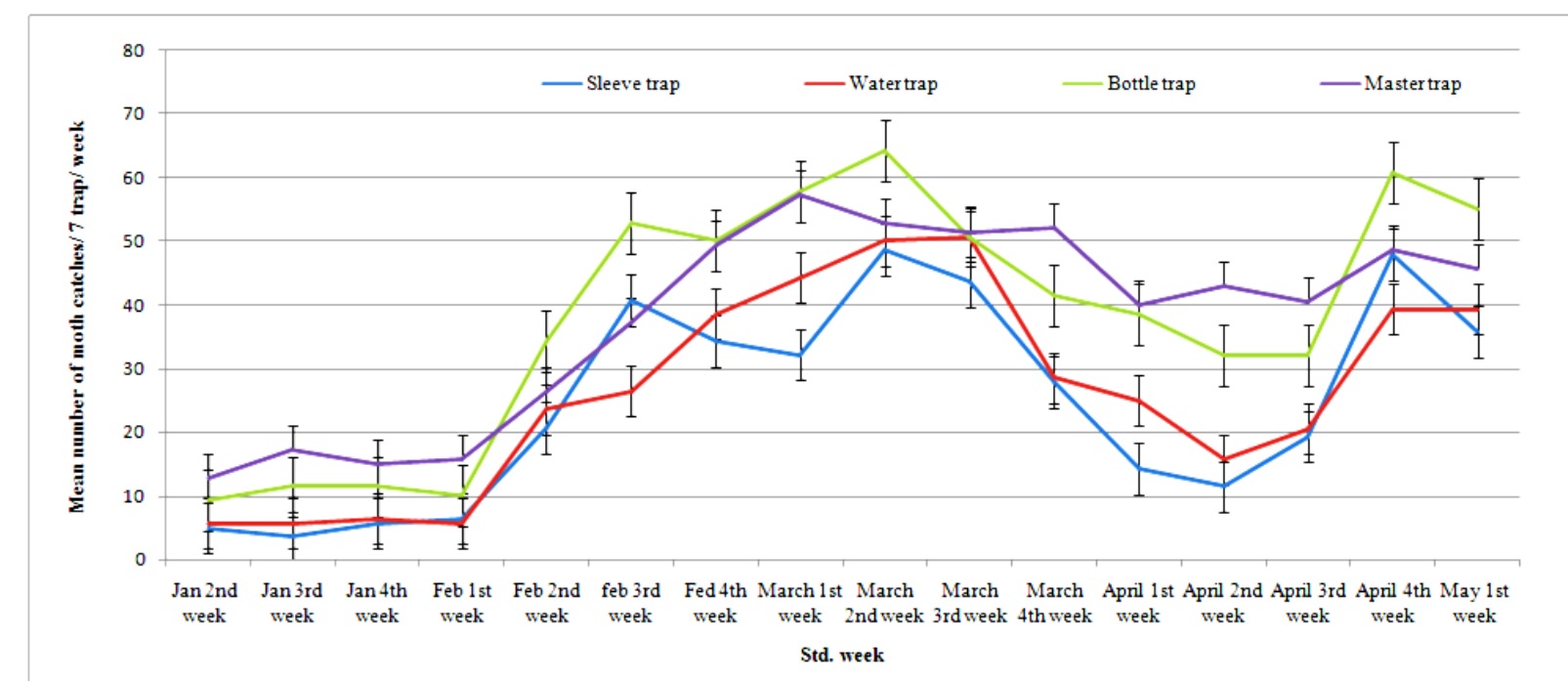

Trap height comparison for integration in L. orbonalis management

Results of observation made on the moth recruitment pattern of indigenous bottle trap at different heights are presented in Table 2 and Fig. 2. Data on the mean number of moths captured among different trap heights tested, trap placed at crop canopy level was found most optimum (3.54 moths/trap/day). The traps placed above the crop canopy level and on ground level attract significantly lower moths (0.49 and 0.56 moths/trap/day). The results of the moth recruitment pattern of indigenous bottle trap placed in different position indicated that among trap heights tested, trap placed at crop canopy level found most optimum. This may be due maximum moth activity just above the plant foliage. The present findings is in line with the observed by the Cork et al. (2003) who reported that the traps placed at crop canopy level to have more 
male moths than traps placed $0.5 \mathrm{~m}$ above or below the crop canopy.

Table 2. Moth retention pattern of indigenous bottle trap placed in different position (On-station experiment)

\begin{tabular}{ccc}
\hline Trap Design & Errections Height & Overall Mean \\
\hline \multirow{2}{*}{ Indigenous bottle trap } & Trap installed in ground level & $0.56^{\mathrm{b}}$ \\
& & $(0.747)$ \\
& Trap installed in canopy level & $3.54^{\mathrm{a}}$ \\
& & $(1.875)$ \\
& Trap installed in above canopy level & $0.49^{\mathrm{c}}$ \\
& SEm & $(0.698)$ \\
SEd & 0.333 \\
CD @ 5\% & 0.473 \\
CD @ 1\% & 0.141 \\
\hline
\end{tabular}

Figures in the parentheses are based on square root transformation, DMRT Fig. 2 Moth retention pattern of indigenous bottle trap placed in different height

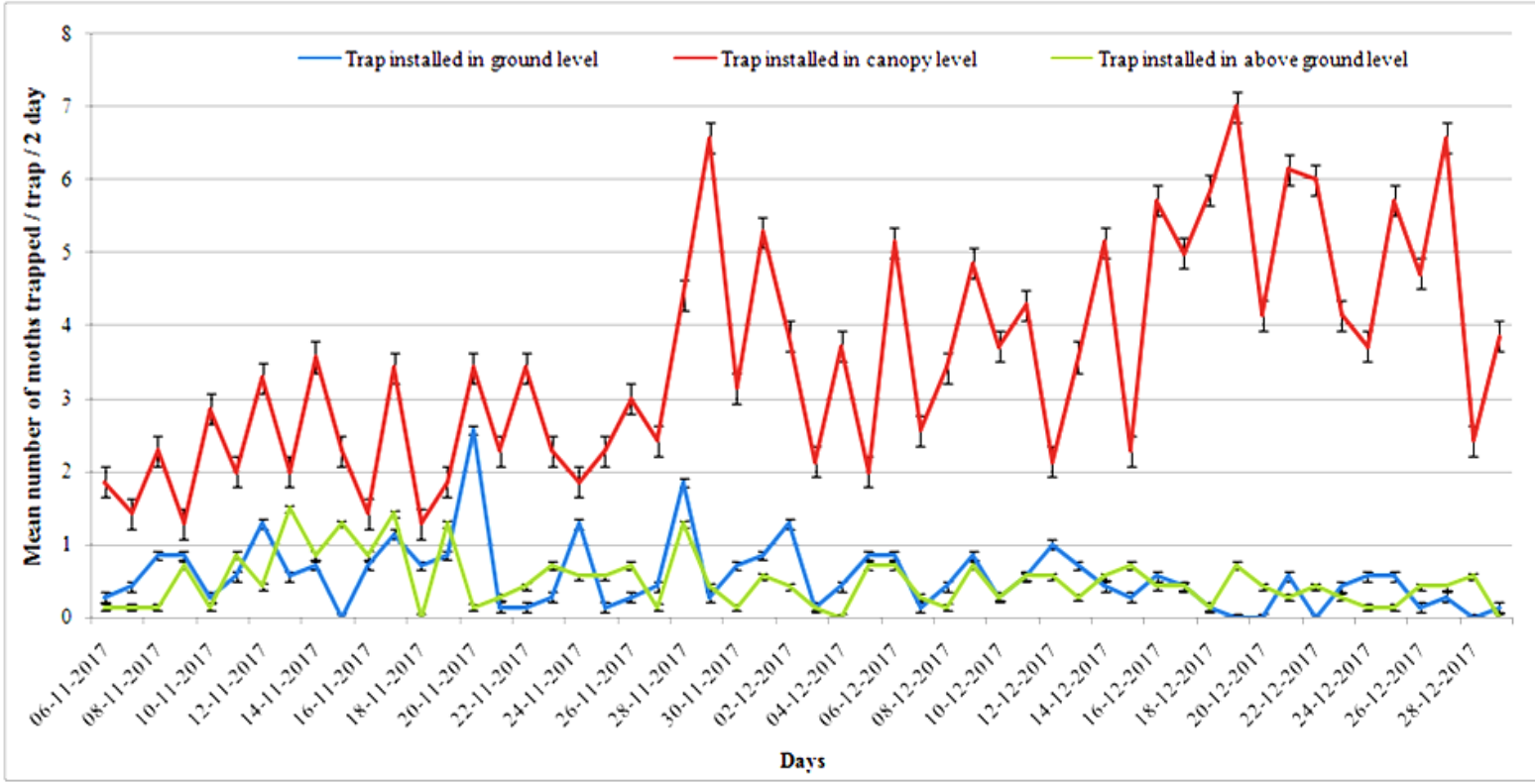

\section{Conclusion}

It can be concluded from the study that the indigenous bottle trap was the most suitable trap to catch the more number of adult moths of Leucinodes orbonalis than the other commercially available traps. Further the study revealed that to install the pheromone trap at the canopy level was most appropriate height.

\section{References}

Alam SN, Rashid MA, Rouf FMA, Jhala RC, Patel JR, Satpathy S \& Ammaranan C. 2003. Development of an integrated pest management strategy for eggplant fruit and shoot borer in South Asia. AVRDC - World Vegetable Center, Taiwan.

Anon 2018. Horticultural Statistics at a Glance. Government of India Ministry of Agriculture and Farmers Welfare 
Department of Agriculture, Cooperation and Farmers Welfare.

Cork A, Alam S, Rouf F \& Talekar N. 2003. Female sex pheromone of brinjal fruit and shoot borer, Leucinodes orbonalis (Lepidoptera: $\quad$ Pyralidae): trap optimization and application in IPM trials. Bulletin of Entomological Research, 93(2): 107-113.

Haldhar SM, Choudhary BR, Bhargava R \& Sharma SK. 2014. Development of an organic integrated pest management (IPM) module against insect-pests of muskmelon in arid region of Rajasthan, India. Journal of Experimental Biology and Agricultural Sciences, 2(1): 19-24
Javed S, Lakshmi KV, Reddy CN, VidyaSagar B \& Shanthi M. 2017. Study of seasonal incidence and impact of abiotic factors on sucking pests of brinjal. Journal of Applied and Natural Science, 9(1): 5154.

Mathi D \& Ravi G. 2018. Influence of intercrops on incidence of shoot and fruit borer Leucinodes orbonalis Guenee. International Journal for Advancements in Agriculture and Research, 5(8): 113121.

Srinivasan R. 2009. Insect and mite pests on eggplant (Vol. 9): AVRDC- World Vegetable Center, Taiwan. 